\title{
ANALISIS KINERJA KEUANGAN PEMERINTAH PROVINSI KALIMANTAN TIMUR TAHUN ANGGARAN 2009 - 2012
}

\author{
Arfandi Arief \\ Fakultas Ekonomi Universitas Mulawarman \\ E-mail: perpusmsi-unmul@gmail.com
}

\begin{abstract}
The purpose of this investigation is to determine the regional financial performance in East Kalimantan. The initial step in this research was determining the variables used, namely: investment and economic growth. Afterward, collecting the data in the form of secondary data (time series) from 2009-2012 files in order to analyze the regional financial performance and the records from 2000-2012 to analyze the influence of investment and growth. Ultimately, the data was examined using multiple regression analysis. The result showed that the regional financial performance of East Kalimantan occupied the level of "good" in terms of independence, effectiveness, and harmony. Not much different, in terms of growth and proportions, their performance was still at the level of "good". Unfortunately, their effort in improving efficiency was still unsuccessful so that they were included in "poor" category. Further analysis showed that investment had positive and significant impact on the regional financial independence of East Kalimantan while economy growth factor did not affect anything.
\end{abstract}

Keywords: Regional Financial Independence, Investment, Economic Growth, PAD, Regional Expenditure

\begin{abstract}
Abstrak
Tujuan penelitian ini menganalisis kinerja keuangan daerah di Propinsi Kaltim. Variabel-variabel yang digunakan meliputi: investasi dan pertumbuhan ekonomi. Data yang digunakan data sekunder (time series) tahun 2009-2012 untuk menganlisis kinerja keuangan daerah, sedangkan untuk menganalisis pengaruh investasi dan pertumbuhan menggunakan data tahun 2000-2012. Data ini di analisis dengan menggunakan regresi berganda. Hasil analisis kinerja keuangan daerah Propinsi Kaltim menunjukkan hasil cukup baik jika ditinjau dari tingkat kemandirian, tingkat efektivitas, dan tingkat keserasian, sedangkan jika ditinjau dari tingkat efisiensi tergolong tidak baik, dan bila ditinjau dari pertumbuhan dan proporsi masih baik. Selanjutnya Hasil analisis menunjukkan variabel investasi berpengaruh positif dan signifikan terhadap kemandirian keuangan daerah di Propinsi Kaltim. Sedangkan pertumbuhan ekonomi tidak berpengaruh terhadap kemandirian keuangan daerah di Propinsi Kaltim.
\end{abstract}

Kata Kunci: Kemandirian Keuangan Daerah, Investasi, Pertumbuhan Ekonomi, PAD, Belanja Daerah 
Kewenangan otonomi daerah yang secara resmi dimulai pada tahun 2001 tersebut, pemerintah daerah mempunyai kewajiban untuk meningkatkan pelayanan dan kesejahteraan masyarakat secara demokratis, adil, merata, dan berkesinambungan. Kewajiban itu dapat dipenuhi apabila pemerintah daerah mampu mengelola potensi daerahnya yaitu potensi sumber daya alam, sumber daya manusia dan potensi sumber daya keuangannya secara optimal.

Salah satu bentuk akuntabilitas pemerintah daerah adalah dalam bidang keuangan daerah. Keuangan daerah merupakan salah satu unsur yang penting dalam menyelenggarakan pemerintahan dan pembangunan daerah. Hal ini menyebabkan diperlukannya suatu pertanggungjawaban keuangan daerah yang memadai. Pertanggungjawaban yang memadai harus mempunyai sifat mudah dimengerti dan memiliki hubungan informasi yang mencerminkan kinerja pemerintahan daerah dalam menyelenggarakan tugas-tugasnya untuk memajukan kesejahteraan masyarakat daerahnya. Akuntabilitas atau pertanggungjawaban pemerintah daerah dalam keuangan daerah memiliki dimensi dan cakupan pengaruh yang sangat besar bagi daerah yang bersangkutan. Dalamkonteks pemerintahan, akuntabilitas mempunyai arti pertangungjawaban yang merupakan salah satu ciri dari terapan pengelolaan pemerintah yang baik (Halim, 2007:254).

Kelemahan utama dalam manajemen keuangan daerah adalah tidak adanya ukuran kinerja yang dapat dijadikan acuan bagi pemerintah daerah dalam proses perencanaan, ratifikasi, implementasi dan evaluasi terhadap keuangan daerah. Selama ini satusatunya ukuran kinerja yang ada adalah ukuran kinerja yang ditentukan oleh pemerintah pusat yaitu aturan bahwa belanja da- erah baik belanja aparatur daerah maupun belanja pelayanan publik yang tertera dalam APBD adalah jumlah maksimal yang dapat dibelanjakan untuk setiap pos belanja daerah. Kinerja belanja daerah disebut baik apabila realisasinya sesuai dengan target yaitu semua dana belanja daerah dihabiskan pada tahun yang bersangkutan.

Analisis kinerja keuangan pada APBD dilakukan dengan membandingkan hasil yang dicapai dari satu periode dengan periode sebelumnya sehingga dapat diketahuibagaimana kecenderungan yang terjadi. Beberapa rasio yang dapat digunakan dalam menganalisis kinerja keuangan yang bersumber dari APBD antara lain: rasio kemandirian untuk menilai tingkat kemandirian keuangan daerah dalam membiayai penyelenggaraan otonomi daerah; rasio efektivitas menggambarkan kemampuan pemerintah daerah dalam mencapai target pendapatan asli daerah; rasio efisiensi untuk mengukur efesiensi dalam merealisasikan pendapatan daerah; rasio keserasian untuk mengetahui bagaimana pengalokasian dana belanja daerah pada belanja aparatur daerah dan belanja pelayanan publik; rasio pertumbuhan untuk mengetahui kemampuan pemerintah daerah dalam mempertahankan dan meningkatkan kinerja sebelumnya; dan rasio proporsi untuk melihat proporsi dari pendapatan dan pengeluaran pemerintah daerah terhadap totalnya (Abdul Halim, 2007:232). Sebagai gambaran awal mengenai APBD, pada Gambar 1disajikan data mengenai Perhitungan APBD Pemerintah Provinsi Kalimantan Timur (Kaltim) dari tahun 2007-2009.

Pada gambar 1 menunjukkan target dan realisasiAPBD Provinsi Kaltim. Di mana realisasi untuk belanja daerah Pemerintah Provinsi Kaltim pada tahun 2009 mencapai sebesar 6.309.259 juta rupiah dari total 


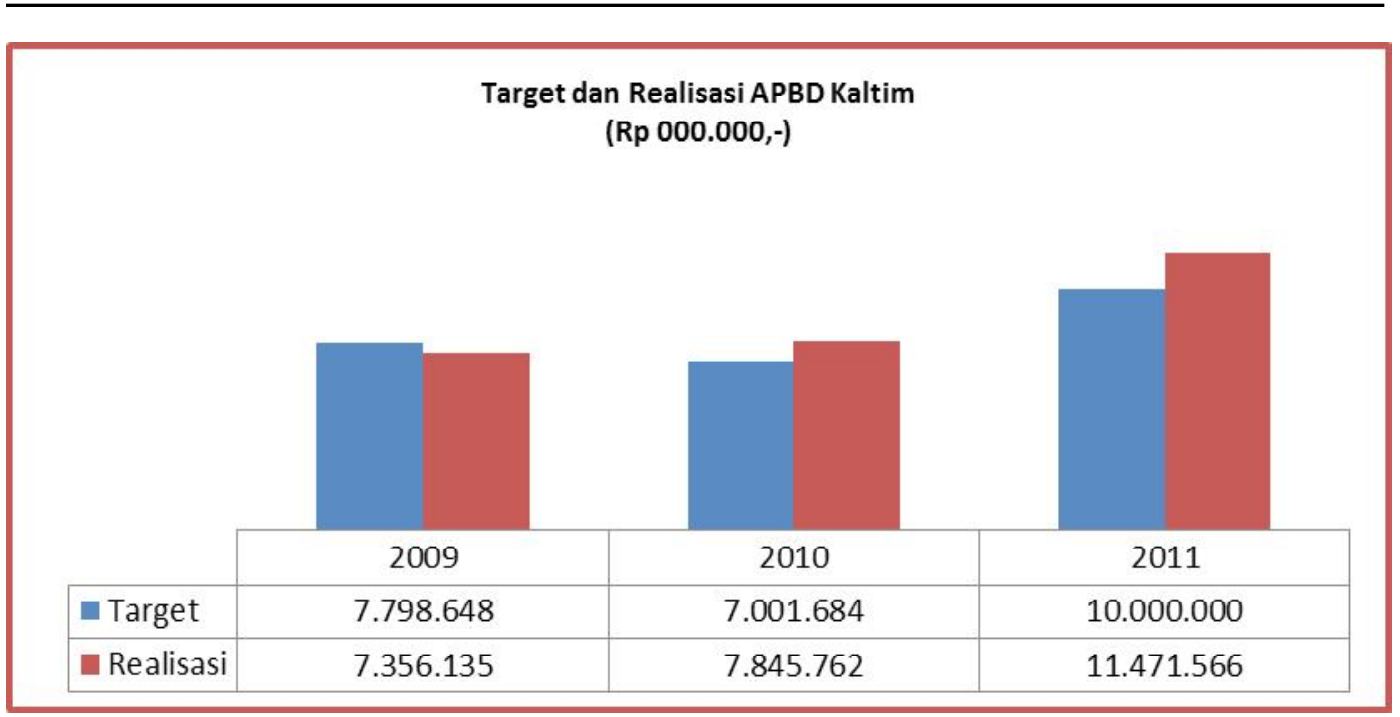

(Sumber: Diolah Dari Kaltim Dalam Angka, BPS 2009-2012)

Gambar 1. Target dan Realisasi APBD Provinsi Kalimatan Timur Tahun Anggaran 20092011.

APBD sebesar 7.356.135 juta rupiah. Pada tahun 2010 realisasi untuk belanja daerah mencapai jumlah sebesar 6.180.394 juta rupiah dari APBD sebesar 7.845.762 juta rupiah. Sedangkan realisasi untuk belanja daerah pada tahun 2011 mencapai jumlah anggaran sebesar 8.142.835 juta rupiah dari APBD sebesar 11.471.566 juta rupiah. Hal tersebut menunjukkan bahwa realisasi belanja daerah pada Pemerintah Provinsi Kaltim tidak melebihiAPBD. Alasan yang mendasari penelitian memilih lokasi dan objek penelitian ini adalah Pemerintah Provinsi Kaltim merupakan salah satu provinsi yang ada di Kalimantan yang memiliki sumber daya cukup banyak untuk menghasilkan pendapatan dalam pajak daerah. Di samping itu PAD yang masih belum optimal, di mana Pemerintah Daerah Provinsi Kaltim dalam melaksanakan pemerintahan, pembangunan, dan juga pelayanan kepada masyarakat memerlukan sejumlah dana untuk membiayai program-program dan kegiatan yang menjadi prioritas daerah.

Informasi yang tersaji pada Gambar 1 belum cukup menggambarkan pencapaian kinerja keuangan daerah pada Pemerintah Daerah Provinsi Kaltim dalam menerapkan otonomi daerah karena pada Gambar 1 tersebut hanya memperlihatkan perbandingan antara anggaran dan realisasinya belum ke tahap perhitungan. Analisis terhadap kinerja keuangan daerah merupakan informasi yang penting terutama untuk membuat kebijakan dalam pengelolaan keuangan daerah dan keberhasilan pemerintah daerah dalam mengelola keuangannya dengan baik. Di samping itu pengukuran kinerja keuangan daerah juga sangat penting untuk menilai akuntabilitas pemerintah daerah dalammemberikan pelayanan publik yang lebih baik. Oleh karena itu, analisis kinerja keuangan daerah baik terhadap perhitungan pendapatan maupun belanja daerah perlu dilakukan.

Penelitian sebelumnya yang digunakan sebagai acuan penelitian ini adalah: Wibowo (2002) meneliti tentang perhitungan APBD tahun anggaran1997/1998 sampai dengan 2001 sebaagi akuntabilitas publik Pemerintah Propinsi Nusa Tenggara Timur. Tujuan penelitian ini adalah untuk mengetahui penyebab terjadinya selisih antara saldo sisa kas 
pada B-IX dengan saldo rekening koran bank. Informasi yang bisa diperoleh dapat diketahui dengan melakukan analisis pada pendapatan maupun belanja dengan menggunakan derajat kemandirian fiskal daerah, rasio keserasian untuk mengetahui prioritas alokasi dana pada belanja rutin dan belanja pembangunan, serta analisis shift and share untuk melihat perkembangan dan proporsi pendapatan maupun belanja. Persamaan penelitian ini dengan penelitian sebelumnya adalah sama-sama menggunakan rasio kemandirian keuangan daerah (otonomi fiskal), rasio keserasian dan analisis shift and share. Sedangkan perbedaannya adalah penelitian ini dalam melakukan perhitungan APBD selain menggunakan rasio di atas juga menggunakan Rasio efektivitas dan efisiensi Pendapatan Asli Daerah. Perbedaan yang lain terletak pada lokasi dan waktu penelitian.

Hasmi (2010) melakukan penelitian tingkat efisiensi dan efektivitas Pengelolaan Keuangan Daerah di Kabupaten Aceh Singkil Pada Era Otonomi Daerah, sejak diberlakukannya Undang-Undang Nomor $22 \mathrm{Ta}-$ hun 1999 tentang Pemerintahan Daerah maka kewenangan yang selama ini masih terpusat atau dekonstrasi dilimpahkan ke daerah atau desentralisasi kecuali tugas-tugas yang masih kewenangan pusat seperti agama, pertahanan, moneter dan lainnya, sehingga daerah yang dahulunya memilikiAnggaran Pendapatan dan Belanja yang sedikit dengan berlakunya otonomi daerah dapat mengelola APBD yang relatif lebih besar, sehingga kecenderungan penggunaan anggaran tidak terkontrol, ini menyebabkan di beberapa daerah peningkatan APBD-nya besar tetapi tidak sejalan dengan peningkatan kesejahteraan penduduknya.

Untuk itu penelitian ini ingin mengetahui apakah APBD Kabupaten Aceh Singkil te- lah dikelola secara efesien dan efektif. Penelitian ini menganalisis struktur hubungan Keuangan Pemerintah Pusat dan Pemerintah Daerah Kabupaten Aceh Singkil dari sisi penerimaan dana transfer seperti Dana Alokasi Umum, Bagi Hasil Pajak dan Bagi Hasil Sumber DayaAlam, kemudian menganalisis pertumbuhan Pendapatan AsliDaerah (PAD) dan keeratan hubungan realisasi penerimaan dengan pengeluaran rutin. Data yang digunakan adalah data sekunder dengan runtut waktu (time series) dalam kurun waktu Tahun Anggaran 2000 sampai dengan 2006. Hasil penelitian ini menunjukan ketergantungan Anggaran Pemerintah Kabupaten Aceh Singkil terhadap Pemerintah Pusat masih sangat besar mencapai 98 persen, ini berarti kemampuan daerah untuk mengali sumbersumber pendapatan asli daerah masih sangat kecil, ke depan diharapkan dapat lebih mengadakan intensifikasi dan ekstensifikasi PAD. Pertumbuhan penerimaan daritahun pertama meningkat sangat tinggi dari Rp.45.822.986.296 pada tahun 2000 menjadi Rp 277.749.484.323 pada akhir tahun 2006, sedangkan penerimaan PAD bersifat fluktuatif pada tahun 2000 Rp. 1.608.264.122 pada akhir tahun penelitian meningkat menjadi Rp.6.199.131.809. Untuk tingkat efisiensi berkisar antara 24 persen sampai dengan 63 persen ini berarti tergolong efisien, sedangkan tingkat efektivitas berkisar antara 96 persen sampai dengan 109 persen tergolong sangat efektif.

Keuangan daerah dapat diartikan sebagai semua hak dan kewajiban yang dapat dinilai dengan uang, demikian pula segala sesuatu baik berupa uang maupun barang yang dapat dijadikan kekayaan daerah sepanjang belum dimiliki/dikuasai oleh negara atau daerah yang lebih tinggi serta pihakpihak lain sesuai dengan ketentuan atau per- 
aturan perundangan yang berlaku (Halim, 2007:23). Dari definisi tersebut dapat diperolehkesimpulan, yaitu: Semua hak adalah hak untuk memungut sumber-sumber penerimaan daerah, seperti: pajak daerah, retribusi daerah, hasil perusahaan milik daerah, dan lain-lain dan atau hak untuk menerima sumber-sumber penerimaan lain seperti dana alokasi umum dan dana alokasi khusus sesuai peraturan yang ditetapkan. Hak tersebut akan menaikkan kekayaan daerah. Semua kewajiban adalah kewajiban untuk mengeluarkan uang yang digunakan untuk membayar tagihan-tagihan kepada daerah dalam rangka menyelenggarakan fungsi pemerintah, infrastruktur, pelayanan umum, dan pengembangan ekonomi. Kewajiban tersebut akan menurunkan kekayaan daerah. 2. Sistem Pengelolaan Keuangan Daerah.

Permendagri No. 13 Tahun 2006 tentang Pedoman Pengelolaan Keuangan daerah menjelaskan bahwa pengelolaan keuangan daerah adalah keseluruhan kegiatan meliputi perencanaan, pelaksanaan, penatausahaan, pelaporan, pertanggungjawaban, dan pengawasan keuangan daerah.

Tuntutan masyarakat terhadap peningkatan pelayanan dan kesejahteraan yang semakin baik, menjadi tantangan bagi pemerintah daerah untuk bekerja secara lebih efisien dan efektif khususnya dalam memberikan layanan kepada masyarakat. Tuntutan tersebut tidak lepas dari peranan pemerintah sebagai pelayan dan pelaksana pembangunan.

Pengelolaan keuangan daerah dilakukan secara tertib, taat pada peraturan perundang-undangan, efisien, ekonomis, efektif, transparan, dan bertanggung jawab dengan memperhatikan asas keadilan, kepatutan dan manfaat untuk masyarakat. Penge- lolaan ini didasarkan pada APBD yang dibuat setiap tahunnya oleh pemerintah daerah dan ditetapkan dengan peraturan daerah.

Karena otonomi daerah bertujuan untuk mencapai Good governance, yaitu pemerintah daerah yang transparan, economies, efficient, effective, responsive, dan accountable. Maka otonomi daerah mengacu pada konsep value of money yang berkaitan dengan pengukuran ekonomis, efisien, dan efektifitas.

Tujuan utama dari pengelolaan keuangan daerah dan organisasi Pemerintah Daerah adalah memberikan pelayanan yang prima bagi masyarakat di daerah yang merupakan klien dari pemerintah daerah. Dalam hal ini, semua unit pemerintah yang ada secara pokok difungsikan untuk melayani dengan sebaik-baiknya masyarakat yang bersangkutan. Untuk dapat berfungsi sebagai public service maka persepsi aparatur pemerintah daerah tentang pelayanan terhadap masyarakat merupakan suatu kunci dalam memberikan kejelasan arah, semakin baik persepsi aparatur pemerintah akan semakin baik pula penyelenggaraan pemerintahan begitu juga sebaliknya

Sesuai dengan Permendagri Nomor 13 Tahun 2006, efisiensi adalah hubungan antara masukan dan keluaran, efisiensi merupakan ukuran apakah penggunaan barang dan jasa yang dibeli dan digunakan oleh organisasi perangkat pemerintahan untuk mencapai tujuan organisasi perangkat pemerintahan dapat mencapai manfaat tertentu. Efisiensi juga mengandung beberapa pengertian antara lain: Efisiensi pada sektor hasil dijelaskan dengan konsep masukankeluaran (input-output). Efisiensi pada sektor pelayanan masyarakat adalah suatu kegiatan yang dilakukan dengan pengorbanan seminimal mungkin; atau dengan kata lain 
suatu kegiatan telah dikerjakan secara efisien jika pelaksanaan pekerjaan tersebut telah mencapai sasaran dengan biaya yang terrendah atau dengan biaya minimal diperoleh hasil yang diinginkan. Efisiensi penyelenggaraan pemerintahan daerah dapat dicapai dengan memperhatikan aspek hubungan dan tatakerja antar instansi pemerintah daerah dengan memanfaatkan potensi dan keanekaragaman suatu daerah.

Berdasarkan pokok permasalahan yang telah diuraikan, maka yang menjadi tujuan dari penelitian ini adalah untuk mengetahui kinerja keuangan Pemerintah Daerah Provinsi Kaltim. Secara lebih lanjut akan diuraikan sebagai berikut, pertama penelitian bertujuan melihat rasio kemandirian (otonomi fiskal), rasio efektivitas PAD, rasio efisiensi keuangan daerah, rasio keserasian, rasio pertumbuhan dan proporsiAPBD pada tahun anggaran 2009-2012. Selain itu penelitian ini ingin melihat keterkaitan antara sisa lebih penganggaran tahun sebelumnya dengan kinerja keuangan Pemerintah Provinsi Kaltim tahun anggaran 2009-2012.

\section{Metode Penelitian}

Variabel yang dianalisis dalam penelitian ini didefinisikan sebagai berikut: Rasio Kemandirian adalah rasio yang menunjukkan kemampuan pemerintah daerah dalam membiayai sendiri kegiatan pemerintahan, pembangunan dan pelayanan kepada masyarakat yang telah membayar pajak dan retribusi sebagai sumber pendapatan yang diperlukan daerah. Rasio kemandirian dapat diukur dengan membandingkan pendapatan asli daerah yang diterima dengan total penerimaan Pemerintah Provinsi Kalimantan Timur.

Rasio efektivitas adalah tingkat pencapaian pelaksanaan suatu kegiatan atau pres- tasi yang dicapai oleh Pemerintah Daerah Provinsi Kalimantan Timur. Rasio efektivitas diukur dengan membandingkan realisasi pendapatan dengan anggaran pendapatan Pemerintah Provinsi Kalimantan Timur.

Rasio Efisiensi adalah tingkat pencapaian pelaksanaan suatu kegiatan atau prestasi yang dicapai oleh Pemerintah Provinsi Kalimantan Timur. Rasio efisiensi diukur dengan membandingkan realisasi biaya untuk memperoleh pendapatan dengan realisasi pendapatan yang diperoleh Pemerintah Provinsi Kalimantan Timur.

Rasio Keserasian adalah rasio yang menggambarkan bagaimana Pemerintah Daerah memprioritaskan alokasi dananya pada belanja aparatur dan belanja pelayanan publik secara optimal. Rasio keserasian dapat diukur dengan dua cara. Pertama dengan membandingkan total sisa anggarandengan total belanja daerah. Kedua dengan membandingkan total pengeluaran lainnya dengan total belanja daerah.

Rasio Pertumbuhan adalah rasio yang mengukur pertumbuhan seberapa besar kemampuan pemerintah daerah dalam mempertahankan dan meningkatkan keberhasilannya yang telah dicapai dalam setiap periode. Rasio pertumbuhan dapat diukur dengan membandingkan antara realisasi penerimaan daerah periode ini dengan realisasi penerimaan daerah periode sebelumnya dibandingkan dengan realisasi penerimaan daerah periode sebelumnya.

Rasio Proporsi APBD adalah analisis share atau proporsi akan menunjukkan prioritas pemerintah dalam mengalokasikan dana untuk belanja.

Investasi adalah Kinerja investasi yang diproksi dariPDRB menurut penggunaannya yang ditunjukkan oleh pembentukan modal tetap ditambah perubahan stok. Pembentu- 
kan modal tetap bruto adalah pengeluaran untuk pengadaan pembuatan atau pembelian barang-barang modal baru (bukan barang konsumsi) baik dari dalam negeri maupun dari luar negeri (impor) termasuk barang bekas modal di Provinsi Kalimantan Timur menurut harga berlaku (BPS, 2006) yang dinyatakan dalam jutaan rupiah.

Pertumbuhan Ekonomi merupakan kondisi perkembangan perekonomian daerah di Provinsi Kaltim dalam jangka waktu tertentu (biasanya satu tahun) berdasarkan laju pertumbuhan PDRB atas harga konstan menurut lapangan usaha yang dinyatakan dalam persentase.

Metode analisis data yang digunakan dalam penelitian ini menggunakan metode analisis kuantitatif, yaitu: melakukan perhitungan-perhitungan terhadap data keuangan yang diperoleh untuk memecahkan masalah yang ada sesuai dengan tujuan penelitian. Dalam penelitian initeknik analisis kuantitatif yang digunakan adalah: (1) Rasio Kemandirian Keuangan Daerah (otonomi fiskal), (2) Pendapatan Asli Daerah (PAD), (3) Rasio Efektivitas, (4) Rasio Efisiensi Keuangan Daerah, (5) Rasio Keserasian, (6) Rasio Belanja Pelayanan Publik Terhadap APBD, (6) Rasio pertumbuhan (analisis shift), (7) Proporsi pendapatan dalamAPBD (analisis share), (8) Analisis Regresi.

\section{Hasil Penelitian dan Pembahasan}

Analisis kemandirian keuangan daerah (otonomi fiskal) terhadap APBD bertujuan untuk mengetahui kemampuan pemerintah daerah dalam membiayai sendiri kegiatan pemerintahan, pembangunan dan pelayanan kepada masyarakat yang membayar pajak dan retribusi sebagai sumber pendapatan yang diperlukan daerah. Analisis ini bertujuan mengetahui pola hubungan antara Pemerintah Pusat dengan Pemerintah Daerah serta kemampuan keuangan sesuai dengan Pola Hubungan dan Tingkat Kemandirian Daerah. Berikut ini disajikan Tabel 5.1 yang memuat rasio kemandirian keuangan daerah pada Pemerintah Provinsi Kaltim untuk tahun anggaran 2009-2012.

Berdasarkan hasil analisis dapat diketahui bahwa rasio kemandirian keuangan daerah Pemerintah Provinsi Kaltim pada tahun 2009, 2010, 2011, dan 2012 adalah sebesar 41,29\%; 38,51\%; 45,86\% dan 45,39\%. Sesuai dengan Tabel 2.2 halaman 37, maka dapat diketahui bahwa pola hubungan antara pemerintah pusat dengan pemerintah daerah serta kemampuan keuangan daerah Pemerintah Provinsi Kaltim pada tahun anggaran 2009, 2010, 2011, dan 2012 berada pada tingkat kemandirian dengan interval 25-50 persen. Hal ini berarti bahwa Pemerintah Provinsi Kaltim mempunyai pola hubungan konsultatif, di mana peranan pemerintah pusat sudah mulai berkurang mengingat daerah yang bersangkutan tingkat kemandiriannya sedikit lebih mampu dalam melaksanakan otonomi daerah. Ini berarti pula bahwa kemampuan keuangan Pemerintah Provinsi Kaltim termasuk dalam kategori rendah.

Selama 4 tahun terakhir diperoleh ratarata rasio kemandirian keuangan daerah pada tahun anggaran 2009-2012 sebesar 42,77\% yang termasuk dalam pola hubungan konsultatif atau termasuk dalamkategori rendah, di mana peranan pemerintah pusat sudah mulai berkurang mengingat daerah yang bersangkutan tingkat kemandiriannya sedikit lebih mampu melaksanakan otonomi daerah. Dengan demikian Pemerintah Provinsi Kaltim diharapkan lebih meningkatkan lagi pendapatan daerah agar pemerintah daerah 
benar-benar mampu dan mandiri dalam melaksanakan urusanotonomidaerah tanpa campur tangan pemerintah pusat lagi.

Tingkat efektivitas dari PAD dapat diketahui dengan menggunakan rasio efektivitas, yaitu rasio yang menggambarkan kemampuan pemerintah daerah dalam merealisasikan PAD yang direncanakan dibandingkan dengan target atau anggaran yang ditetapkan berdasarkan potensi riil daerah (Halim, 2007:234) Di mana kriteria sangat efektif dengan rasio di atas $100 \%$, kriteria efektif dengan rasio 90\%-100\%, kriteria cukup efektif dengan rasio $80 \%$ - 90\%, kriteria kurang efektif dengan rasio 60\% - 80\% dan kriteria tidak efektif dengan rasio di bawah 60 persen ke atas. Tabel 3 berikut menyajikan rasio efektifitas PAD Pemerintah Provinsi Kaltimtahun anggaran 2009-2012. Analisis tingkat efisiensi keuangan daerah dapat dihitung dengan menggunakan rasio efisiensi, yaitu rasio yang menggambarkan perbandingan antara total realisasi pengeluaran (Belanja Daerah) dengan realisasi pendapatan yang diterima (Abdul Halim, 2007:234). Rasio efisiensi keuangan daerah dapat dihitung dengan menggunakan rumus. Analisis efisiensi pengelolaan keuangan daerah dimaksudkan untuk mengetahui seberapa besar efisiensi dari suatu pelaksanaan

Tabel 1. Perhitungan Rasio Efektivitas Pendapatan Asli Daerah (PAD) Pemerintah Provinsi Kalimantan Timur Tahun Anggaran 2009-2012 (Rp 000.000,-)

\begin{tabular}{cccc}
\hline $\begin{array}{c}\text { Tahun } \\
\text { Anggaran }\end{array}$ & Anggaran & Realisasi & $\begin{array}{c}\text { Efektivitas } \\
(\%)\end{array}$ \\
\hline 2009 & 1.994 .760 & 2.208 .309 & $110,71 \%$ \\
2010 & 2.280 .359 & 2.711 .300 & $118,90 \%$ \\
2011 & 3.984 .052 & 4.503 .239 & $113,03 \%$ \\
$2012^{*)}$ & 4.690 .480 & 5.409 .949 & $115,34 \%$ \\
\multicolumn{2}{c}{ Rata-rata Rasio Efektivitas Tahun 2009-2012 } & $114,49 \%$ \\
\hline
\end{tabular}

Keterangan: *) data sementara.

Tabel 2. Perhitungan Tingkat Efisiensi Belanja Daerah Terhadap Pendapatan Daerah Pemerintah Provinsi Kalimantan Timur Tahun Anggaran 2009-2012 (Rp 000.000,-)

\begin{tabular}{cccc}
\hline $\begin{array}{c}\text { Tahun } \\
\text { Anggaran }\end{array}$ & $\begin{array}{c}\text { Total Realisasi Belanja } \\
\text { Daerah }\end{array}$ & $\begin{array}{c}\text { Total Realisasi } \\
\text { Pendapatan Daerah }\end{array}$ & $\begin{array}{c}\text { Efisiensi } \\
(\%)\end{array}$ \\
\hline 2009 & 6.309 .259 & 5.348 .926 & $117,95 \%$ \\
2010 & 5.918 .568 & 7.041 .041 & $84,06 \%$ \\
2011 & 8.142 .835 & 9.819 .129 & $82,93 \%$ \\
$2012 *)$ & 11.339 .765 & 11.904 .745 & $95,25 \%$ \\
& Rata-rata Rasio Efisiensi Tahun 2009-2012 & $95,05 \%$ \\
\hline
\end{tabular}

Keterangan: *) data sementara. 
kegiatan atau proyek dengan melakukan perbandingan antara output/pengeluaran dengan input/masukan. Di mana kriteria sangat efisien dengan rasio dibawah 60 persen, kriteria efisien dengan rasio 60\%-80\%, kriteria cukup efisien dengan rasio $80 \%$ $90 \%$, kriteria kurang efisien dengan rasio 90\%-100\% dan kriteria tidak efisien dengan rasio $100 \%$ ke atas. Tingkat efisiensi belanja daerah terhadap pendapatan daerah Pemerintah Daerah Provinsi Kaltim tahun anggaran 2009-2012 untuk mengetahuinya dapat dilihat pada Tabel 2 .
Rasio keserasian adalah rasio yang menggambarkan bagaimanapemerintah daerah memprioritaskan alokasi dananya pada belanja aparatur daerah dan belanja pelayanan publik secara optimal (Abdul Halim, 2007:235). Semakin tinggi persentase dana yang dialokasikan untuk belanja aparatur daerah berarti persentase belanja pelayanan publik yang digunakan untuk menyediakan sarana prasarana ekonomi masyarakat cenderung semakin kecil.

Berdasarkan Tabel 3 dapat diketahui bahwa total belanja aparatur daerah ter-

Tabel 3. Perhitungan Rasio Keserasian Belanja Daerah Pemerintah Provinsi Kaltim Tahun Anggaran 2009-2012.

\begin{tabular}{|c|c|c|c|c|c|}
\hline \multirow{2}{*}{ No. } & \multirow{2}{*}{ Uraian } & \multicolumn{4}{|c|}{ Tahun Anggaran } \\
\hline & & 2009 & 2010 & 2011 & 2012 \\
\hline 1. & $\begin{array}{l}\text { Total Belanja } \\
\text { Aparatur Daerah } \\
\text { (Belanja Tidak } \\
\text { Langsung) } \\
\text { Total Belanja } \\
\text { Pelayanan Publik } \\
\text { (Belanja }\end{array}$ & $3.568 .626,65$ & $3.157 .121,46$ & 4.679.991,71 & $6.126 .151,18$ \\
\hline & Langsung) & $3.388 .722,51$ & $2.761 .446,81$ & $3.462 .843,74$ & $5.213 .614,01$ \\
\hline 3. & $\begin{array}{l}\text { Total Belanja } \\
\text { Daerah }\end{array}$ & $6.957 .349,16$ & $5.918 .568,27$ & $8.142 .835,45$ & $11.339 .765,19$ \\
\hline 4. & $\begin{array}{l}\text { (Total Belanja } \\
\text { Aparatur } \\
\text { Daerah/Total } \\
\text { Belanja Daerah) }\end{array}$ & & & & \\
\hline 5. & $\begin{array}{l}\text { x } 100 \% \\
\text { (Total Belanja } \\
\text { Pelayanan } \\
\text { Publik/Total } \\
\text { Belanja Daerah) }\end{array}$ & $51,29 \%$ & $53,34 \%$ & $57,47 \%$ & $54,02 \%$ \\
\hline Rat: & $\begin{array}{l}\text { x } 100 \% \\
\text {-rata Total Belanja }\end{array}$ & $48,71 \%$ & $46,66 \%$ & $42,53 \%$ & $45,98 \%$ \\
\hline Apa & $\begin{array}{l}\text { ratur Daerah/ Total } \\
\text { Belanja Daerah }\end{array}$ & & & $03 \%$ & \\
\hline $\begin{array}{l}\text { Rat } \\
\text { Pela }\end{array}$ & $\begin{array}{l}\text {-rata Total Belanja } \\
\text { yanan Publik/Total } \\
\text { Belanja Daerah }\end{array}$ & & & $97 \%$ & \\
\hline
\end{tabular}


Ekonomika-Bisnis Vol. 4 No.1 Bulan Januari Tahun 2013. Hal 63-76

hadap total belanja daerah Pemerintah Provinsi Kaltim pada tahun anggaran 2009 sebesar $51,29 \%$; tahun anggaran 2010 sebesar 53,34\%; tahun 2011 sebesar 57,47\%; dan tahun anggaran 2012 sebesar 54,02\%. Sehingga rata-rata total belanja aparatur daerah terhadap total belanja daerah Pemerintah Provinsi Kaltim untuk tahun anggaran 2009-2012 sebesar 54,03\%. Total belanja pelayanan publik terhadap total belanja daerah pada tahun anggaran 2009 sebesar 48,71\%; tahun anggaran 2010 sebesar 46,66\%; tahun 2011 sebesar 42,53\%; dan tahun anggaran 2012 sebesar 45,98\%. Sehingga rata-rata total belanja pelayanan publik terhadap total belanja daerah Pemerintah Provinsi Kaltim tahun anggaran 2009-2012 sebesar 45,97\%.

Analisis rasio pertumbuhan (shift) bertujuan untuk mengukur seberapa besar kemampuan pemerintah daerah dalam mempertahankan dan meningkatkan keberhasilannya yang telah dicapai dari periode ke periode berikutnya. Analisis rasio pertumbuhan dapat digunakan untuk mengetahui perkembangan APBD, baik dari sisi pendapatan maupun dari sisi pengeluarannya atau belanja daerah.
Pemerintah daerah tidak mempunyai kewenangan untuk mengatur penerimaan daerah selain PAD. Tabel 4 di bawah menyajikan rasio pertumbuhan PAD Pemerintah Provinsi Kaltim tahun anggaran 20092012.

Berdasarkan Tabel 4 maka rata-rata pertumbuhan PAD Pemerintah Provinsi Kaltimuntuk tahun 2009 terhadap tahun sebelumnya menunjukkan pertumbuhan yang positif sebesar $6,67 \%$. Pertumbuhan PAD terbesar terjadi pada sumber lain-lain PAD sebesar $46,23 \%$, sedangkan pertumbuhan PAD terkecil atau mengalami penurunan terjadi pada sumber penerimaan dari retribusi sebesar -96,92\%. Pada tahun 2012 rata-rata pertumbuhan PAD mengalami peningkatan dari tahun sebelumnya yaitu sebesar 20,13\%. Hal ini disebabkan oleh peningkatan retribusi daerah sebesar $64,21 \%$, peningkatan pajak daerah sebesar $21,93 \%$ sedangkan sumber lain-lain PAD tumbuh sebesar $16,52 \%$. Namun terjadi penurunan pada sumber hasil pengelolaan kekayaan daerah lainnya yang dipisahkan hanya sebesar 3,41\%. Rata-rata pertumbuhan PAD terhadap pendapatan daerah Pemerintah Provinsi Kaltim selama tahun 2009-2012 se-

Tabel 4. Perhitungan Rasio Pertumbuhan Pendapatan Asli Daerah (PAD) Pemerintah Provinsi Kaltim Tahun Anggaran 2009-2012.

\begin{tabular}{|c|c|c|c|c|c|c|}
\hline \multirow[b]{2}{*}{ No. } & \multirow[b]{2}{*}{ Sumber PAD } & \multicolumn{4}{|c|}{ Tahun Anggaran (\%) } & \multirow{2}{*}{$\begin{array}{c}\text { Rata-rata } \\
(\%)\end{array}$} \\
\hline & & 2009 & 2010 & 2011 & $\underset{)}{2012 *}$ & \\
\hline 1. & Pajak Daerah & $-1,40$ & 31,45 & 81,79 & 21,93 & 33,44 \\
\hline 2. & Retribusi Daerah & $-96,92$ & 91,88 & 26,99 & 64,21 & 21,54 \\
\hline 3. & $\begin{array}{l}\text { Hasil Pengelolaan Kekayaan } \\
\text { Daerah Lainnya yg Dipisahkan }\end{array}$ & 64,60 & 13,63 & 56,71 & $-3,41$ & 32,88 \\
\hline 4. & Lain-lain PAD & 114,80 & $-0,54$ & 10,31 & 16,52 & 35,27 \\
\hline & Rata-rata Pertumbuhan PAD & 6,67 & 22,78 & 66,09 & 20,13 & 28,92 \\
\hline
\end{tabular}

Keterangan: *) data sementara. 
besar $28,92 \%$ dan menunjukkan pertumbuhan yang positif. Hal ini memberikan gambaran keberhasilan Pemerintah Provinsi Kaltim dalammeningkatkan PAD. Rata-rata pertumbuhan pajak daerah sebesar 33,44\%, retribusi daerah sebesar $21,54 \%$, hasil pengelolaan kekayaan daerah lainnya yang dipisahkan sebesar 32,88\% dan lain-lain PAD sebesar $35,27 \%$.

Pertumbuhan belanja aparatur daerah/ belanja tidak langsung Pemerintah Provinsi Kaltim tahun anggaran 2009-2012 disajikan pada tabel 7. Berdasarkan tabel 7 menunjukkan bahwa rasio pertumbuhan untuk tahun 2009 mengalami penurunan dari tahun sebelumnya yaitu: sebesar $10,96 \%$ sedangkan pada tahun 2012 mengalami pertumbuhan sebesar 30,90\%. Rata-rata pertumbuhan belanja aparatur daerah/belanja tidak langsung Pemerintah Provinsi Kaltim untuk tahun anggaran 2009-2012 sebesar $11,33 \%$ yang menunjukkan pertumbuhan yang positif. Rasio pertumbuhan belanja aparatur daerah yang terbesar terjadi pada tahun 2011 yaitu: sebesar 48,24\%.

Pertumbuhan belanja pelayanan publik/belanja langsung Pemerintah Provinsi
Kaltim tahun anggaran 2009-2012 disajikan pada tabel 5.7. Tabel ini bahwa belanja pelayanan publik/belanja langsung Pemerintah Provinsi Kaltim tahun anggaran 2009-2012 menunjukkan rata-rata pertumbuhan yang positif sebesar $20,35 \%$. Hal ini disebabkan adanya peningkatan yang tinggi dalam pembelanjaan modal. Pembelanjaan modal dilakukan untuk mendukung program-program yang dilakukan pemerintah dalam rangka meningkatkan kinerja pemerintah daerah.

Analisis share terhadap APBD bertujuanuntuk mengetahuiproporsidari setiapkomponen pendapatan terhadap total pendapatan daerah serta proporsi setiap komponen belanja terhadap total belanja daerah, baik belanja aparatur daerah/belanja tidak langsung maupun belanja pelayanan publik/ belanja langsung.

Nilai penduga tidak bias dan efisiensi dari suatu persamaan regresi berganda diperoleh dengan metode kuadrat terkecil biasa ( $\mathrm{Or}$ dinary Least Square), maka analisis data dilakukan beberapa tahap sebagai berikut: (1) Uji Asumsi Klasik, (2) Uji kelayakan Model, dan (3) pengujian hipotesis (uji-t).

Tabel 5. Perhitungan Rasio Pertumbuhan Belanja Aparatur Daerah/Belanja Tidak Langsung Pemerintah Provinsi Kaltim Tahun Anggaran 2009-2012.

\begin{tabular}{ccc}
\hline Tahun & $\begin{array}{c}\text { Realisasi } \\
(\text { Rp 000.000,-) }\end{array}$ & $\begin{array}{c}\text { Rasio Pertumbuhan } \\
(\%)\end{array}$ \\
\hline 2009 & 3.568 .627 & $-10,96$ \\
2010 & 3.157 .121 & $-11,53$ \\
2011 & 4.679 .992 & 48,24 \\
$2012 *)$ & 6.126 .151 & 30,90 \\
& Rata-rata & 11,33 \\
\hline
\end{tabular}

Keterangan: *) data sementara. 
Hasil analisis regresi menunjukkan bahwa adanya pengaruh positif antara investasi daerah terhadap tingkat kemandirian keuangan daerah di Kaltim yang menunjukkan hasil signifikan, hal ini dibuktikan dengan nilai t-hitung sebesar 3,152 dan angka probabilitas signifikansi sebesar 0,010 yang lebih kecil dari 0,05 juga memperkuat bukti bahwa investasi daerah berpengaruh signifikan terhadap tingkat kemandirian keuangan daerah di Kaltim. Hal ini menjelaskan bahwa semakin tinggi investasi daerah akan berdampak pada peningkatan tingkat kemandirian keuangan daerah di Kaltim atau dapat dikatakan jika semakin banyak investasi daerah yang dialokasikan dari APBD, maka tingkat kemandirian keuangan daerah diperoleh provinsi Kaltim akan semakin besar, karena deviden dari hasil investasi daerah yang disetor ke kas daerah semakin besar.

\section{Penutup}

Berdasarkan pembahasan dan hasil evaluasi yang telah dikemukakan pada bab sebelumnya, dapat disimpulkan bahwa kinerja keuangan Pemerintah Provinsi Kaltim Tahun Anggaran 2009-2012 tergolong cu- kup baik jika ditinjau dari tingkat kemandirian, tingkat efektivitas, dan tingkat keserasian, sedangkan jika ditinjau dari tingkat efisiensi tergolong tidak baik, dan bila ditinjau dari pertumbuhan dan proporsi masih baik.

Tingkat kemandirian keuangan provinsi Kaltim tergolong sedang yaitu sebesar $42,77 \%$ yang berarti bahwa sebesar 57,23\% masih tergantung pada pemerintah pusat. Dengan demikian pemerintah Provinsi Kaltim diharapkan lebih meningkatkan lagi pendapatan daerah agar pemerintah daerah benar-benar mampu dan mandiri dalam melaksanakan urusan pemerintah daerah tanpa campur tangan pemerintah pusat lagi.

Tingkat efektivitas terhadap PAD menunjukkan bahwa rata-rata tingkat efektivitas PAD Pemerintah Provinsi Kaltim selama tahun anggaran 2009-2012 sebesar $114,49 \%$ yang berarti sangat efektif, karena pada interval di atas $100 \%$. Hal ini menggambarkan kinerja Pemerintah Provinsi Kaltim yang baik dalam merealisasikan PAD yang telah direncanakan.

Tingkat efisiensi rata-rata keuangan daerah Pemerintah Provinsi Kaltim selama tahun anggaran 2009-2012 sebesar 107,33\% yang tergolong tidak efisien. Karena berada pada interval di atas $100 \%$. Hal ini disebab-

Tabel 6. Perhitungan Rasio Pertumbuhan Belanja Pelayanan Publik/Belanja Langsung Pemerintah Provinsi Kaltim Tahun Anggaran 2009-2012

\begin{tabular}{ccc}
\hline \multirow{2}{*}{ Tahun } & $\begin{array}{c}\text { Realisasi } \\
(\text { Rp 000.000,-) }\end{array}$ & $\begin{array}{c}\text { Rasio Pertumbuhan } \\
(\%)\end{array}$ \\
\hline 2009 & 3.388 .723 & 44,29 \\
2010 & 2.761 .447 & $-18,51$ \\
2011 & 3.462 .844 & 25,40 \\
$2012 *)$ & 5.213 .614 & 50,56 \\
\multicolumn{2}{r}{ Rata-rata Rasio Pertumbuhan } & 20,35 \\
\hline
\end{tabular}

Sumber: diolah dari tabel lampiran 1.

Keterangan: *) data sementara. 
kan oleh realisasi pendapatan daerah yang sedikit lebih besar daripada realisasi belanja daerah.

Tingkat keserasian belanja daerah Pemerintah Provinsi Kaltim tahun anggaran 2009-2012 menunjukkan bahwa sebagian besar dana pada anggaran daerah dialokasikan pada belanja aparatur daerah/belanja tidak langsung dengan persentase ratarata $54,03 \%$, sedangkan sisanya sebesar 45,97\% dialokasikan untuk belanja aparatur daerah/belanja tidak langsung.

Tingkat pertumbuhan (shift) rata-rata pada Pemerintah Daerah Provinsi Kaltim tahun anggaran 2009-2012 sebesar 28,92\% menunjukkan pertumbuhan yang positif untuk pertumbuhan $\mathrm{PAD}$ dan belanja aparatur daerah/belanja tidak langsung menunjukkan rata-rata pertumbuhan positif sebesar 11,33\%. Sedangkan untuk belanja pelayanan publik/ belanja langsung menunjukkan rata-rata pertumbuhan positif sebesar 20,35\%.

Tingkat proporsi (share) pada Pemerintah Provinsi Kaltim tahun anggaran 20092012 menunjukkan kontribusi terbesar untuk pendapatan daerah ditempati oleh dana perimbangan rata-rata sebesar $56,17 \%$. Sedangkan kontribusi terbesar untuk belanja daerah ditempati oleh belanja aparatur dae$\mathrm{rah} /$ belanja tidak langsung sebesar 55,35\%.

Hasil estimasi regresi berganda menunjukkan investasi berpengaruh signifikan dan mempunyai hubungan yang positif terhadap tingkat kemandirian keuangan daerah di Propinsi Kaltim dengan hasil uji t pada tingkat signifikansi sebesar 0,10. Arah positif ini menunjukkan bahwa peningkatan investasi akan menyebabkan meningkatnya kemandirian fiskal.

Variabel pertumbuhan ekonomi berpengaruh negatif terhadap tingkat kemandirian keuangan daerah Provinsi Kaltim, te- tapi tidak signifikan dari hasil ujit pada tingkat signifikansi sebesar 0,384 .

\section{DAFTAR PUSTAKA}

Adi, Priyo Hari. 2007. Kemampuan Keuangan Daerah dan Relevansinya dengan Pertumbuhan Ekonomi. The 1st National Accounting Conference. Departemen Akuntansi, Fakultas Ekonomi Universitas Indonesia. Jakarta.

2009. Fenomena Ilusi Fiskal Dalam Kinerja Anggaran Pemerintah. Jurnal Akuntansi dan Keuangan, Vol.6, No.1.

Anonim. Statistik Kalimantan Timur. Berbagai edisi penerbitan, BPS Kalimantan Timur.

Ringkasan APBD Provinsi. Berbagai edisi penerbitan, BPS Kalimantan Timur. 2006. Akuntansi Sektor Publik: Suatu Pengantar. Erlangga. Jakarta.

Firmansyah. 2008. Modul Praktek Ekonomika Dasar: Estimasi, Asumsi Klasik dan Variabel Dummy Aplikasi Eviews 4.0. LSKE. Semarang.

Halim, Abdul. 2002. Akuntansi dan Pengendalian Keuangan Daerah. Seri Bunga Rampai Manajemen KeuanganDaerah. UUPAMPYKPN. Yogyakarta. 2004. Akuntansi Sektor

Publik: Akuntansi Keuangan Daerah. Salemba Embat. Jakarta. 
Ekonomika-Bisnis Vol. 4 No.1 Bulan Januari Tahun 2013. Hal 63-76

2007. Akuntansi Keuangan Daerah (EdisiTiga). SalembaEmpat. Jakarta.

Hasmi, Ali. 2010. Analisis Efisiensi Dan Efektivitas Pengelolaan Keuangan Daerah Di Kabupaten Aceh Singkil Pada Era Otonomi Daerah. Tesis S2 Sekolah Pasca Sarjana USU Medan.

Kuncoro, Mudrajad. 1995. "Desentralisasi Fiskal di Indonesia: Dilema Otonomi dan Ketergantungan", Prisma, No.4, $3-17$.

Kuncoro, Mudrajad. 1997. Ekonomi Pembangunan, Teori, Masalah dan Kebijakan. UPP AMD YKPN. Yogyakarta.

Kuncoro, Mudrajad. 2004. Otonomi \& Pembangunan Daerah. Erlangga. Jakarta.

Manan, Bagir. 1994. Hubungan Keuangan Antara Pemerintah Pusat dan Daerah di Indonesia. Rajawali Pers. Jakarta.

Mardiasmo. 2000. "Paradigma Baru Pengelolaan Keuangan Daerah Untuk Menyongsong Pelaksanaan otonomi Daerah 2001" Seminar Isu terakhir Menjelang Pelaksanaan Otonomi Daerah Tahun 2001. HIMMEP, Yogyakarta.

Santosa, Purbayu Budi. 2005. Analisis Pendapatan Asli Daerah (PAD) dan Faktor-Faktor Yang Mempengaruhinya dalam Upaya Pelaksanaan Otonomi Daerah di Kabupaten Kediri. Jurnal Dinamika Pembangunan, Vol.2, No.1, Ilmu Ekonomi Studi Pembangunan Fakultas Ekonomi Universitas Diponegoro. Semarang.
Susilo, Gideon T.B., dan Priyo Hari Adi. 2007. Analisis Kinerja Keuangan Anggaran Pendapatan dan Belanja Daerah Sebelum dan Sesudah Otonomi Daerah (Studi Empiris di Propinsi Jawa Tengah) Paper disajikan pada Konferensi Penelitian Akuntansi dan Keuangan Sektor Publik Pertama. Surabaya. 